\title{
Human factors and ergonomics in the context of COVID-19: Planning for concepts insertion in a productive systems discipline
}

\author{
Rosley Anholon ${ }^{\mathrm{a}}$, Izabela Simon Rampasso ${ }^{\mathrm{a}, \mathrm{b}, *}$ and Robert E. Cooper Ordóñez ${ }^{\mathrm{a}}$ \\ ${ }^{a}$ School of Mechanical Engineering, University of Campinas, Campinas, São Paulo, Brazil \\ ${ }^{\mathrm{b}}$ PNPD/CAPES Program, Doctoral Program in Sustainable Management Systems, \\ Federal Fluminense University, Niterói, Rio de Janeiro, Brazil
}

Received 7 September 2020

Accepted 20 September 2020

\begin{abstract}
.
BACKGROUND: The COVID-19 pandemic is challenging companies worldwide and undergraduate courses need to consider this context within their disciplines, especially regarding human factors and ergonomics. For this, professors should plan how to insert this knowledge into the program content of their discipline.

OBJECTIVE: This commentary aims to present how this insertion will be conducted in the second academic semester of 2020 in the discipline "Productive Systems" of the mechanical engineering undergraduate course offered by a Brazilian university.

METHODS: This commentary is based on the authors' points of view and experiences. However, the presented discussion is based on institutional websites and international articles.

RESULTS: It is possible to verify that human factors and ergonomic aspects related to the pandemic can be debated in several topics of the analyzed discipline.

CONCLUSIONS: Besides presenting the planning of inserting these aspects, this commentary expands the debates on the subject.
\end{abstract}

Keywords: Coronavirus disease, COVID-19, engineering education, Brazil, human factors, ergonomics

\section{Human factors and ergonomics in the context of COVID-19}

The mechanical engineering course offered at the University of Campinas stands out as one of the most traditional in Brazil. It is recognized for its excellence, having trained many professionals over a few decades. The current curriculum is characterized by

${ }^{*}$ Address for correspondence: Izabela Simon Rampasso, School of Mechanical Engineering, University of Campinas, Mendeleyev Street, 200 Campinas, São Paulo, Brazil. E-mail: izaramp asso@gmail.com. disciplines in the areas of thermal and fluids, mechanical design, computational mechanics, materials and manufacturing processes. Within the latter area, there is a discipline called "Productive Systems", in which the main objective is to provide future mechanical engineers with a broad view of operations management.

In its current conception, "Productive Systems" addresses concepts related to the evolution of production systems, work organization, general concepts on operations management, group technology, industrial productivity, production planning and control, 
material requirement planning (MRP) I and MRP II, theory of constraints, layout types, Toyota production system and its evolution to lean manufacturing and fundamentals of Industry 4.0. Since "Productive Systems" is a discipline within a manufacturing engineering area, it presents a little more emphasis on manufacturing systems; however, since many students are likely to work in management positions, the professors responsible for this discipline also consider include different forms of work that exist (face-to-face, virtual, flexible, etc.).

Every year, the professors seek to complement the discipline content based on market demands. In recent years, for example, sustainability issues have been discussed with students during the discipline, and this experience is reported in an article called: "Developing in engineering students a critical analysis about sustainability in productive systems: empirical evidences from an action research experience" [1].

The current scenario marked by the COVID-19 pandemic evidenced the need to better emphasize the human factors and ergonomics. In this sense, the professors of this discipline and other researchers involved started to discuss ways to complement students training, without reducing the content already ministered that are still important. It is important to be noted that the discipline is not entirely dedicated to the analysis of human factors and ergonomics in the production systems; thus, it is necessary to insert these concepts at specific moments in the program content. Based on the context of COVID-19 and the reality of Brazilian companies, the authors of this text aim to demonstrate how this insertion will be conducted in the second academic semester of 2020.

Regarding the topic "evolution of productive systems", it is intended to show students that sometimes this evolution occurred through the need of companies to adapt to the existing conditions; this was the case, for example, of Japanese companies in the postWorld War II era. Those companies needed to produce in small spaces, efficiently and to meet the demand of domestic market. Under these conditions, the replication of the Fordist model based on large manufacturing units was not feasible, creating a need for a new model [2], with reduced wastes and higher productivity [3]. The students of the mechanical engineering course at University of Campinas will be questioned about how much we are witnessing a new breaking point in production systems, since companies are searching for ways to adapt their productive arrangements considering the recommendations of
World Health Organization (WHO) [4] -until at least the development of an effective vaccine. In addition, it is intended to emphasize to students that regardless of the situations they will experience in their professional lives, human factors and ergonomics should always be relevant in the analysis of any productive system.

Another topic of the program content is "work organization". In this topic, it is intended to present the evolution of administrative schools that contributed in different ways to structuring the work environment. Among the themes presented, issues related to the management of human resources, different types of work (face-to-face, virtual, flexible, among others) and concepts of physical, cognitive and organizational ergonomics disseminated by the International Ergonomics Association (IEA) and the Brazilian Association of Ergonomics will be addressed [5, 6]. Regarding different forms of work, COVID-19 forced companies to abruptly adopt work from home (WFH) [7]. However, there is still much to be discussed about the implications of this modality in terms of human factors and ergonomics [8]. The main difficulties experienced by professionals who started to work from home, highlighting aspects of stress, personal/professional life management in the same environment, ergonomic aspects in a work environment not evaluated by competent professionals, among other aspects will be discussed. In relation to industrial systems, in addition to the themes traditionally addressed, we intend to discuss with students aspects of ISO 45001 standard in the context of COVID-19 (objectives of occupational health and safety systems; injuries and health problems; concept of danger and risk (3.20), among others) [9].

We understand that the topics "types of layout", "industrial productivity" and "production planning and control" have a very close correlation to be discussed in light of the concepts of human factors in the context of the current pandemic. It is aimed, for example, to present the configuration of a production cell with five employees in its traditional design and, next, to debate with students how to meet the requirements recommended by WHO in order to minimize the risks of contamination. The aim is to compare productivity in these two situations, to discuss implications for production planning and control and to ask students to think about possible solutions to meet the demand while respecting the associated human factors.

Regarding the topic "Toyota production system" and its evolution to lean manufacturing, debates have 
been conducting using information presented in the article "Primary problems associated with the health and welfare of employees observed when implementing lean manufacturing projects" [10]. These debates will be expanded to also consider the context of COVID-19. Finally, the topic entitled "Fundamentals of Industry 4.0 " will be presented, in which it will be debated how new technologies related to Industry 4.0 [11] can contribute to reduce accidents, stress levels of employees and also to minimize contamination risks.

As previously mentioned, the presented content is a plan for the insertion of topics associated with human factors and ergonomics in the context of productive systems operation of Brazilian companies. We believe that the dissemination of information in advance, even in its execution phase, can motivate and assist other professors who teach disciplines associated with operations management and expand the debates about how to use the current challenges to enhance future professionals training.

\section{Acknowledgments}

This work was supported by Conselho Nacional de Desenvolvimento Científico e Tecnológico (CNPq) under grants 307536/2018-1, and by Coordenação de Aperfeiçoamento de Pessoal de Nível Superior Brasil (CAPES) - Finance Code 001, under process 88887.464433/2019-00.

\section{Conflict of interest}

None to report.

\section{References}

[1] Rampasso IS, Anholon R, Silva D, Cooper Ordóñez RE, Quelhas OLG, Santa-Eulalia LA De. Developing in engineering students a critical analysis about sustainability in productive systems: Empirical evidences from an action research experience. Int J Sustain High Educ. 2019;20:22944. https://doi.org/10.1108/IJSHE-03-2018-0048.

[2] Heloani R. Gestão e organização no capitalismo globalizado: história da manipulação psicológica no mundo do trabalho. São Paulo: Atlas; 2012.

[3] Tortorella GL, Fettermann DC, Piñeres A, Gaiardelli P. The moderating role of just-in-time on sociotechnical practices' effect over quality and workers' health. Hum Factors Ergon Manuf Serv Ind. 2019;29:210-23. https://doi.org/ 10.1002/hfm.20776.

[4] WHO. Coronavirus disease (COVID-19) advice for the public 2020. https://www.who.int/emergencies/diseases/novelcoronavirus-2019/advice-for-public (accessed August 30, 2020).

[5] ABERGO. Associação Brasileira de Ergonomia 2020. http://www.abergo.org.br/ (accessed August 30, 2020).

[6] IEA. Human Factors/Ergonomics (HF/E): Definition and Applications 2020. https://iea.cc/what-is-ergonomics/ (accessed August 30, 2020).

[7] Dwivedi YK, Hughes DL, Coombs C, Constantiou I, Duan Y, Edwards JS, et al. Impact of COVID-19 pandemic on information management research and practice: Transforming education, work and life. Int J Inf Manage. 2020:102211. https://doi.org/10.1016/j.ijinfomgt.2020.102211.

[8] Davis KG, Kotowski SE, Daniel D, Gerding T, Naylor J, Syck M. The Home Office: Ergonomic Lessons From the "New Normal." Ergon Des 2020. https://doi.org/10. $1177 / 1064804620937907$.

[9] ISO. ISO 45001 - Sistema de gestão de saúde e segurança ocupacional - requisitos com orientação para o uso. Rio de Janeiro: ABNT; 2018.

[10] Rampasso IS, Anholon R, Gonçalves Quelhas OL, Filho WL. Primary problems associated with the health and welfare of employees observed when implementing lean manufacturing projects. Work. 2017;58:263-75. https://doi.org/10.3233/WOR-172632.

[11] Cordeiro GA, Ordóñez REC, Ferro R. Theoretical proposal of steps for the implementation of the Industry 4.0 concept. Brazilian J Oper Prod Manag. 2019;16:166-79. https://doi.org/10.14488/BJOPM.2019.v16.n2.a1. 